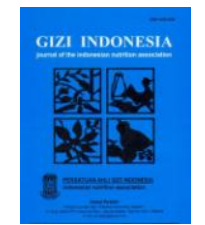

\title{
THE SITUATION OF URINARY IODINE CONCENTRATION (UIC) AMONG SCHOOL AGE CHILDREN, WOMEN AT REPRODUCTIVE AGE AND PREGNANT WOMEN IN INDONESIA: THE ANALYSIS OF RISKESDAS 2013
}

\author{
Status lodium Anak Usia Sekolah, Wanita Usia Reproduktif dan Wanita Hamil di Indonesia: \\ Analisis Data Riskesdas 2013
}

Djoko Kartono', Atmarita², Abas B. Jahari', Soekirman², Doddy lzwardy ${ }^{3}$

${ }^{1}$ National Institute for Health Research and Development (NIHRD), Ministry of Health, Republic of Indonesia, Jakarta, Indonesia

2Nutrition Foundation for Food Fortification, Indonesia

${ }^{3}$ Directorate of Community Nutrition, Ministry of Health

E-mail: kartono.djoko@yahoo.com

\begin{abstract}
lodine Deficiency Disorders (IDD) are the leading cause of goiter, cretinism, developmental delays and other health problems. lodine deficiency is an important public health issue as it is a preventable cause of intellectual disability. While elimination of iodine deficiency is imperative, it should be noted that excessive intake of iodine can also lead to adverse health effects. This paper analyzed the iodine status using median urinary iodine concentration (MUIC) of school age children (SAC), women of reproductive age (WRA), and pregnant women (PW) who live in the same household from Riskesdas 2013. The total number of households included in the analysis was 13,811 households, from which 6,149 SAC (aged 6 12 years), 13,218 WRA (aged 15-49 years), and 578 PW (aged 15-49 years) were enumerated. The national MUIC of SAC, WRA and PWwas in the normal range indicated that the iodine status was adequate using WHO epidemiological criteria. lodine status in some sub-populations indicated deficiency, however, in terms of geographic characteristics people who live in the urban has better iodine status compared to rural areas. Similarly, populations in richer economic quintiles had better iodine status. Only pregnant women in the $1^{\text {st }}$ and $2^{\text {nd }}$ quintile were deficient. Almost all regions in Indonesia showed the MUIC was in the normal adequate range, except NTT-NTB, Maluku-Papua, and East Java for pregnant women who tend to have lower MUIC ( $<150 \mu \mathrm{g} / \mathrm{L})$. The status of iodized salt at the household was detected using both Rapid Test Kit/RTK as well as Titration. The result demonstrated a strong association between salt iodine level and iodine status. The MUIC for all three groups were lower when the iodine level in salt was lower, then increased when the levels of iodine content in salt increased. The iodine status of pregnant women consuming non-iodized salt was inadequate. The detrimental effect of iodine deficiency on the mental and physical development of children as well as on the women of reproductive age has been recognized. Indonesia still needs the salt iodization program to keep the iodine status in the normal range. In particular coverage with adequately iodized salt needs to be improved in order to improve the iodine status of pregnant women. For the prevention of lodine disorders (insufficient), monitoring should be undertaken in regular basis to assess the MUIC, especially for pregnant women.
\end{abstract}

Keywords: MUIC, School age children, women reproductive age, pregnant women

\section{ABSTRAK}

Kekurangan lodium adalah penyebab utama terjadinya gondok, kretinisme, keterlambatan perkembangan dan masalah kesehatan lainnya. Kekurangan iodium merupakan masalah kesehatan masyarakat yang penting dikaitkan dengan intelektual. Eliminasi kekurangan iodium sangat penting, akan tetapi perlu dicatat bahwa asupan berlebihan dari iodium juga dapat menyebabkan efek kesehatan yang merugikan. Artikel ini menganalisis status iodium anak usia sekolah, wanita usia reproduktif dan wanita hamil yang tinggal di rumah yang sama, yang datanya bersumber dari Riskesdas 2013. Jumlah rumah tangga yang dianalisis adalah 13.811, yang didalamnya ada 6.149 anak usia sekolah 6-12 tahun, 13.218 wanita usia reproduktif usia 15-49 tahun, dan 578 ibu hamil usia 15-49 tahun. Hasil penelitian menunjukkan bahwa status iodium yang ditunjukkan oleh Median Urinary lodine Concentrarion/MUIC pada anak usia sekolah, 
wanita usia reproduktif, maupun ibu hamil masih dalam kisaran normal menurut kriteria epidemiologi WHO. Menurut karakteristik, penduduk yang tinggal di perkotaan memiliki status iodium yang lebih baik dibandingkan dengan daerah perdesaan. Demikian pula pada populasi di kuintil ekonomi kaya status iodium juga lebih baik, hanya ibu hamil termiskin di kuintil 1 dan 2 yang butuh perhatian. Hampir semua daerah di Indonesia menunjukkan MUIC berada dalam kisaran normal, kecuali pada Provinsi NTT, NTB, Maluku, Papua, dan Jawa Timur, ibu hamil cenderung memiliki MUIC rendah (<150 $\mu \mathrm{g} / \mathrm{L})$. Situasi garam beriodium di rumah tangga juga telah dilakukan deteksi dengan menggunakan Test Cepat/lodina test dan juga metode titrasi. Hasilnya menunjukkan lebih baik menggunakan titrasi dari test cepat untuk mengamati hubungan asupan iodium dan status iodium. MUIC untuk ketiga kelompok penduduk lebih rendah bila tingkat asupan garam iodium lebih rendah, kemudian meningkat ketika tingkat kandungan iodium dalam garam meningkat. Efek merugikan dari kekurangan iodium pada perkembangan mental dan fisik anak serta pada wanita usia reproduktif telah diakui. Indonesia masih membutuhkan program iodisasi garam untuk menjaga status iodium penduduk dalam kisaran normal. Untuk pencegahan defisiensi iodium, dan mempertahankan MUIC pada kondisi normal, pemantauan masih harus dilakukan secara teratur, terutama untuk ibu hamil.

Kata kunci: kadar iodium dalam urine, anak usia sekolah, wanita usia subur, wanita hamil

\section{INTRODUCTION}

O ne of the major nutrition problems in Indonesia is lodine Deficiency Disorders (IDD). The human body requires only small amounts of iodine to be consumed, but it has important roles and functions. ${ }^{1}$ lodine deficiency is a condition when there is insufficient iodine in the diet, and lead to goiter or cretinism in its most severe forms, but also results in developmental delays and other health problems. lodine deficiency is an important public health issue as it is a preventable cause of intellectual disability. ${ }^{2}$

High intakes of iodine can cause some of the same symptoms as iodine deficiency including goiter, elevated TSH level, and hyperthyroidism, because excess iodine inhibits thyroid hormone synthesis and thereby increases TSH stimulation, which can cause goiter. lodine-induced hyperthyroidism can also result from high iodine intakes, usually when iodine is introduced in areas that had long been endemic for iodine deficiency. 3,4

Indonesia has made an effort to reduce iodine deficiency, particularly through the use of iodized salt in the daily diet. ${ }^{5}$ The effort to track this program and coverage of households with iodized salt in Indonesia has been implemented since 1998, included on an annual basis as part of the National Socio-Economic Survey (Susenas) through 2003, and subsequently in 2007 and 2013 through National Basic Health Research (Riskesdas)a. Both data collection

\footnotetext{
a Both Susenas and Riskesdas are the national surveys, which sampling frame has designed by
}

were using the same Rapid test kit (RTK). There was 65.2 per cent households consumed lodized salt in 1998 and reached 73.2 per cent in 2003 , but it was down to 62.3 per cent in 2007 and increased again to 77.1 per cent in 2013.6,7

National surveys on the iodine status have been carried out in 2003, and as part of Riskesdas in 2007 and 2013, which suggest that the iodine status of the population was optimal at national level. Data from Riskesdas 2007 on school age children showed optimal iodine status with Median Urinary Concentration (MUIC) of $224 \mathrm{ug} / \mathrm{L}^{8}$

The data from the Riskesdas 2013 were further analyzed in order to better understand the iodine status of Indonesian population. This paper presents data on the iodine status of three distinct age groups; school age children, women of reproductive age and pregnant women, and matched these individuals within households where possible.

\section{METHODS}

The primary data source for the analysis was Riskesdas 2013, which was designed as a cross sectional survey. The population was all households in the entire country of Indonesia having equal probability of being included. The sample of households and household members in this survey was designed to provide

Central bureau of statistic/CBS using selected census block. 
statistically representative estimates for all parameters at the national and provincial level, and for some additional parameters at the district level. Overall, Riskesdas 2013 collected information from almost 300,000 households and more than 1 million individuals and included many public health indicators. Riskesdas 2013 also collected blood and urine samples for measuring various biomedical parameters, which were national sub-samples.

Analyses of iodine status was based on the results of 300,000 households, which were tested their iodized salt level using rapid test kit (called iodina test provided by Kimia Farma), and 25,000 households representing national level for urine samples of school age children, and women of reproductive aged 15-49 years, including the pregnant women, as well as the household salt for titration. In every selected household, only 1 woman of reproductive age/WRA and 1 school age children/SAC 6-12 years were asked for urine sample. Kish Table was used for selection if there were more than 1 WRA or 1 SAC in the household. lodine source from water was taken from 3000 households out of 25,000 households.

The analysis focused on Median Urinary lodine Concentration (MUIC) of School age children (SAC), Women at Reproductive Age 15-49 years (WRA) and Pregnant Women (PW) based on i) geographic characteristics; ii) RTK's test; and iii) titration. The geographic characteristics included: place of residence (urban-rural), regions, socio-economic status, and salt production areas/provinces.

The analysis was based on the availability of total number of Urinary lodine Concentration (UIC) from SAC, WRA, and PW after data collected and cleaned the outliers, which has 0 values of UIC. Table 1 presented the final samples included in the analysis: SAC (aged 6 - 12 years), WRA aged $15-49$ years, PW (aged $15-49$ years).

\section{Data Analysis}

To answer the research questions, the data of urinary iodine concentration (UIC) were analysed using the median value and observation based on the category of each population groups for UIC data ${ }^{2,9}$ :

$\checkmark$ SAC and WRA:

a. UIC less than $100 \mu \mathrm{g} / \mathrm{L}$ as insufficient iodine intake;

b. UIC between $100-299 \mu \mathrm{g} / \mathrm{L}$ as adequate, and

c. UIC equal and greater than $300 \mu \mathrm{g} / \mathrm{L}$ as excessive;

Pregnant women:

a. UIC less than $150 \mu \mathrm{g} / \mathrm{L}$ as insufficient iodine intake,

b. UIC between $150-499 \mu \mathrm{g} / \mathrm{L}$ as adequate (that is combination of $150-249 \mu \mathrm{g} / \mathrm{L}$ as adequate and $250-499 \mu \mathrm{g} / \mathrm{L}$ as more than adequate, while

c. UIC equal and greater than $500 \mu \mathrm{g} / \mathrm{L}$ as excessive iodine intake.

Category for place or residence was urban and rural, and category for socio-economic status:

a. Q1-lowest economic status (poorest)

b. Q2-low economic status

c. Q3-middle economic status,

d. Q4-middle high economic status,

e. Q5-highest economic status (richest)

Category for regions consist of 9 grouped into Sumatera, Kalimantan, Sulawesi, West Java - Banten, Central Java, East Java, Jakarta-Bali, DIY, NTB-NTT, Maluku-Papua. And also the observation of MUIC has categorized the regions into two: Salt Production Provinces (West Java, Central Java, East Java, South Sulawesi, NTB, and NTT), and other provinces as Non Salt Production.

Table 1

Total Samples Included in the Analysis

\begin{tabular}{lccc}
\hline Total Samples & Median UIC & RTK's test & Titration \\
\hline Pregnant women & 578 & 575 & 484 \\
Women Reproductive Age & 13218 & 13146 & 11164 \\
School children & 6149 & 6116 & 5142 \\
\hline Total & 19945 & 19837 & 16790 \\
\hline
\end{tabular}


The analysis also observed the situation of MUIC in terms of testing iodine level for each group (SAC, WRA, and PW) and iodized salt at household level using Rapid Test Kit (RTK) as well as Titration. The category for RTK's test (semi quantitative) was divided into three colorbased iodine test: Adequate, Inadequate, No-lodine. For the purpose of the analysis, the RTK was classified into two: lodized and Nonlodized. For titration was divided into four: Nonlodized (0-4.9 ppm); inadequate iodized (5.0$17.9 \mathrm{ppm})$, adequate iodized (18.0 - $49.9 \mathrm{ppm})$, and over-iodized ( $\geq 50 \mathrm{ppm}$ ). In all analyses the data were weighted by sample proportion of the population, and the analysis used SPSS-IBM Version 21 with bootstrapping for the value of UIC for each observation to see the median (lower, upper), and interquartile range (IQR).

The number of minimum samples observed for all categories mentioned above should be at least 125 . The term of UIC used in this analysis was based on urine sample that was collected at only one spot of time that was in the morning (between 8-11 am).

This analysis was part of Riskesdas data collection 2013, which has informed consent obtained from all households and the member of households before enrollment.

\section{RESULTS}

The following analysis has observed the MUIC based on 2 comparisons: (i) Geographic characteristics: Urban-rural, socio-economic status, regions, and salt production areas; (ii) Household lodized Salt levels: RTK and Titration.

\section{Geographic characteristics}

It was presented at Figure 1 that the National level of lodine status of SAC, WRA, and Pregnant women was just sufficient: 215, 189 , and $169 \mu \mathrm{g} / \mathrm{L}$ respectively. The median of UIC for all groups of population were varied by place of residence and socio-economic status. People who live in rural were likely to have lower median of UIC than urban population. People who were classified as lower quintile also tend to have lower median value of UIC compared to higher quintiles. Comparing with WHO criteriab for SAC, WRA, and pregnant

\footnotetext{
b WHO criteria for defining iodine sufficiency: median UIC: $150-249 \mu \mathrm{g} / \mathrm{L}$ for pregnant women, 100-199 $\mu \mathrm{g} / \mathrm{L}$ for SAC and WRA.
}

women, only pregnant women who were classified as $1^{\text {st }}$ and $2^{\text {nd }}$ quintile are insufficient.

Table 1 presented the analyses using bootstrapping to observe the Median UIC as well as Interquartile range (IQR) for each group based on characteristics.

The Median UIC of SAC and WRA indicated that iodine status was adequate nationally, in both urban and rural areas, on all regions and for all economic quintiles. However, iodine status was lower in rural areas, amongst poorer quintiles and in the regions of NTB-NTT, Maluku + Papua, Sulawesi, and Sumatera.

It was a little bit problem for presenting the pregnant women data due to a small sample size $(<125),{ }^{10}$ the MUIC showed lower than 150 $\mu \mathrm{g} / \mathrm{L}$ for socio-economic levels (Q1, Q2), and in the regions of East Java, NTB-NTT, and Maluku-Papua. The value of IQR in almost all categories was outside of the range of 150 $249 \mu \mathrm{g} / \mathrm{L}$, except for the region of East Java, and by place of residence (urban, rural), and as expected urbanwas better than rural. The wide interquartile range (IQR) value was shown only in the NTB - NTT that was 64.0 to $488 \mu \mathrm{g} / \mathrm{L}$.

\section{Level of Household lodized Salt: RTK and Titration}

Table 2 presented the analyses using bootstrapping to observe the Median UIC as well as Interquartile range (IQR) for each group based on household lodized salt level for both semi quantitative and titration methods.

Comparison of MUIC value for the three group of population (SAC, WRA, and PW) which figuring the household iodized salt level based on RTK - showed that there was no significant different between iodized and noniodized, except for pregnant women.

However, result of Titration for MUIC of the three group of population (SAC, WRA, and PW) has provided more clear patterns. The MUIC for all groups tend to be lower for the non-iodized salt $(<5 \mathrm{ppm})$ and then increased as the level of iodized salt increased. All MUIC values were within the normal range for SAC, WRA, and $P W$, except for pregnant women from the group non-iodized salt (MUIC: 114.0; 86.1 - 139.5 $\mu \mathrm{g} / \mathrm{L})$.

There was interesting finding on the result of titration. It was shown that iodine status of SAC and WRA was adequate in the population consuming non-iodized salt. This implies iodine 
intake from sources other than household salt. Highest iodine status was in those consuming over-iodized salt, however it was found that a very small proportion of households had overiodized salt. On the other hand iodine status was lower in household with inadequately iodized salt and almost half has inadequately iodized salt.
Table 3 presented the comparison of the iodine status of SAC, WRA, and PW by all level of socio-economic status (Q1 to Q5). The median value of UIC was consistent for three groups of population. It was shown that people who were classified as lower iodine status in the household using non-iodized salt and gradually increased in the household using inadequate, adequate, and over-iodized salt.

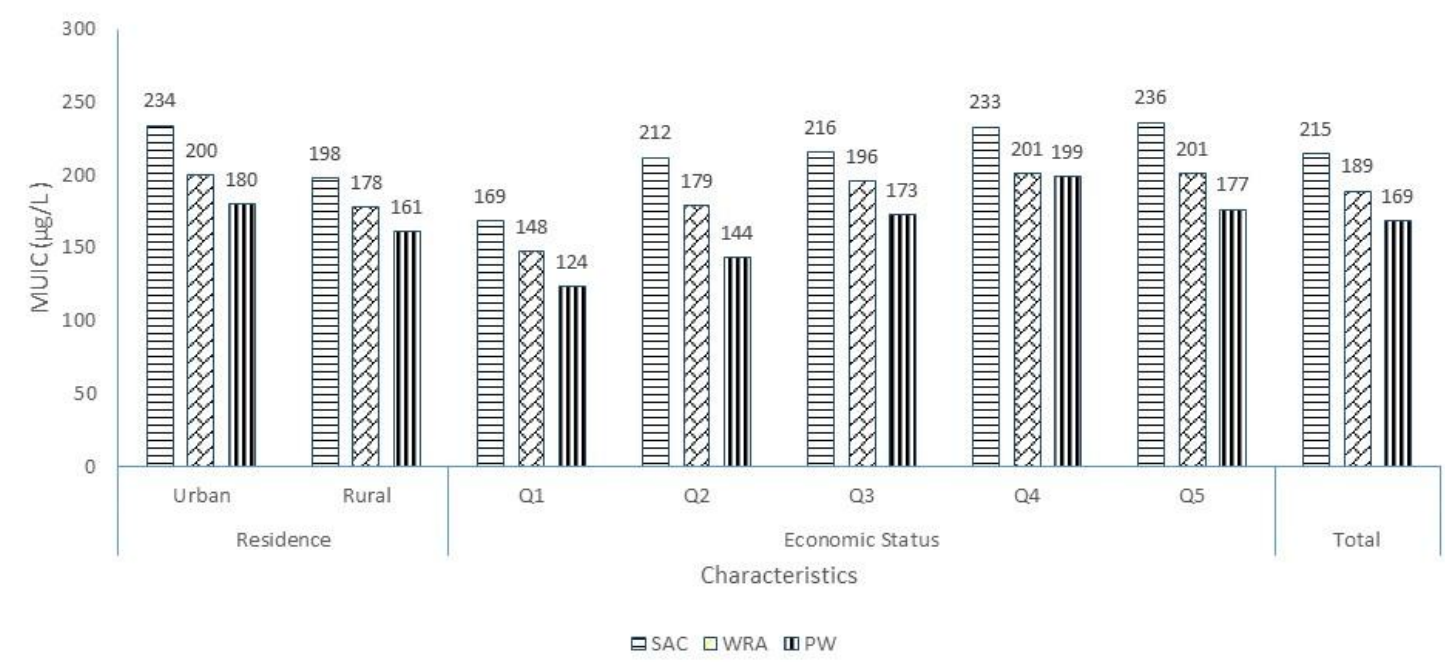

Figure 1

Median Value of UIC $(\mu \mathrm{g} / \mathrm{L})$ of SAC, WRA, and Pregnant women by place of residence and socio-economic status, 2013

\section{DISCUSSION}

lodine is one of the essential micronutrient required for normal human growth and development. ${ }^{11}$ The iodine deficiency as a result mainly from geographical rather than social and economic conditions. ${ }^{12}$ The long-term national efforts to control and eradicate IDD with iodized salt in Indonesia indicating the sufficient level of lodine status of the people that represented by SAC, WRA and PW. Only in the some areas, especially for the poorest and the poor (Q1, Q2), in the region of NTB-NTT as well as Maluku-Papua for pregnant women required more attention to prevent fetal development.

Based on the result of titration, the presence of iodine in salt in the household was related to a higher MUIC among School Age Children, Women at Reproductive Age, and Pregnant Women compared to the households without access to iodized salt. However, the use of RTK to determine the presence of iodine in salt in the households need to be evaluated for the future purpose of monitoring.
The study also noted the wide range of interquartile value, such as in the group of pregnant women in the region of NTB-NTT $(64.0$ - 488.0). This need to be evaluated in terms of deficient or excessive of iodine status, which cannot be eliminated by changing dietary habits. ${ }^{13}$ Based on the assessment above, double burden for iodine issues in Indonesia still cannot be determined. Besides iodine deficiency, a variety of other environmental and geographic characteristics, economic status factors operate to iodine problems, which is related to thyroid dysfunctions. ${ }^{14}$

lodine deficiency remains the single cause of preventable brain damage and mental retardation. ${ }^{15}$ The insufficient iodine among pregnant women can cause the fetus cannot produce enough thyroxin and fetal growth is retarded. ${ }^{16}$ For Indonesia the case of insufficient iodine is only found among pregnant women of the lowest first and second quintiles. Meanwhile, the excessive iodine is not likely to occur for both school aged children and also women of reproductive age. 
Table 1

Comparison of MUIC ( $\mu \mathrm{g} / \mathrm{L})$ by Geographical Characteristics among School Age Children, Women at Reproductive Age, and Pregnant Women, 2013

\begin{tabular}{|c|c|c|c|c|c|c|c|c|c|}
\hline \multirow{3}{*}{ Geographical characteristics. } & \multicolumn{9}{|c|}{ Urinary lodine Concentration $(\mu \mathrm{g} / \mathrm{L})$} \\
\hline & \multicolumn{3}{|c|}{ School Age Children } & \multicolumn{3}{|c|}{ Women at Reproductiive Age } & \multicolumn{3}{|c|}{ Pregnant Women } \\
\hline & $\mathrm{N}$ & Median (Low er; Upper) & Interquartile range & $\mathrm{N}$ & Median (Low er; Upper) & Interquartile range & $\mathrm{N}$ & Median (Low er; Upper) & Interquartile range \\
\hline National & 6149 & $215(211.0 ; 220.0)$ & $192.0-207.0$ & 13218 & $189.0(186.0 ; 191.0)$ & $186.0-191.0$ & 578 & $169(160 ; 180.5)$ & $154.0-194.0$ \\
\hline \multicolumn{10}{|l|}{ Residence } \\
\hline Urban & 2852 & $234(228.0 ; 242.0)$ & $196.0-213.0$ & 6384 & $200.0(196.0 ; 204.0)$ & $184.0-196.0$ & 298 & $180(162.5 ; 199.47)$ & $156.0-207.0$ \\
\hline Rural & 3297 & $198(191.0 ; 204.9)$ & $181.0-200.0$ & 6834 & $178.0(174.0 ; 182.0)$ & $177.0-189.0$ & 280 & $161(160.0 ; 180.5)$ & $154.0-194.0$ \\
\hline \multicolumn{10}{|l|}{ Socio Econom ic Status } \\
\hline Q1 (Poorerst & 1008 & $168.5(157.0 ; 180.0)$ & $165.0-195.0$ & 1867 & $148.0(141.0 ; 156.0)$ & $156.0-175.0$ & 80 & $123.5(112.0 ; 146.0)$ & $86.0-171.0$ \\
\hline Q2 & 1193 & $212.0(202.0 ; 221.0)$ & $175.0-195.0$ & 2493 & $179.0(171.0 ; 187.0)$ & $176.0-195.0$ & 92 & $143.5(113.0 ; 176.5)$ & $117.0-192.0$ \\
\hline Q3 & 1360 & $215.5(207.0 ; 228.9)$ & $178.0-207.0$ & 2973 & $196.0(189.0 ; 201.0)$ & $176.0-194.0$ & 135 & $173.0(157.0 ; 193.0)$ & $140.0-211.0$ \\
\hline Q4 & 1459 & $233.0(223.0 ; 246.0)$ & $199.0-226.0$ & 3216 & $201.0(196.0 ; 206.0)$ & $183.0-201.0$ & 151 & $199.0(175.0 ; 244.6)$ & $145.0-247.0$ \\
\hline Q5 (Richest) & 1129 & $236.0(227.0 ; 248.0)$ & $190.0-216.0$ & 2669 & $201.0(195.0 ; 207.0)$ & $180.0-198.0$ & 120 & $178.5(157.0 ; 213.5)$ & $142.0-244.0$ \\
\hline \multicolumn{10}{|l|}{ Region \& Sub-region } \\
\hline Sumatera & 1185 & $189.0(182.0 ; 201.0)$ & $163.0-190.0$ & 2499 & $180.0(173.0 ; 186.9)$ & $163.0-190.0$ & 132 & $176.5(153.5 ; 199.0)$ & $119.0-220.0$ \\
\hline Kalimatan & 315 & $239.0(214.0 ; 261.9)$ & $198.0-252.0$ & 694 & $194.0(186.5 ; 211.5)$ & $172.0-214.0$ & 28 & $190.0(127.0 ; 258.5)$ & $121.0-266.0$ \\
\hline Sulaw esi & 505 & $198.0(185.0 ; 209.0)$ & $155.0-192.0$ & 896 & $169.0(153.0 ; 177.9)$ & $153.0-182.0$ & 31 & $154.0(70.0 ; 196.0)$ & $111.0-250.0$ \\
\hline West Java-Banten & 1399 & $230.0(220.0 ; 241.0)$ & $194.0-221.0$ & 3116 & $189.0(183.0 ; 193.9)$ & $171.0-189.0$ & 134 & $182.5(160.0 ; 203.0)$ & $140.0-201.0$ \\
\hline Central Java & 809 & $260.0(248.0 ; 273.0)$ & $218.0-257.0$ & 1854 & $240.0(229.5 ; 252.0)$ & $210.0-238.0$ & 81 & $208.0(163.0 ; 264.0)$ & $167.0-316.0$ \\
\hline East Java & 1068 & $211.0(199.5 ; 223.5)$ & $173.0-201.0$ & 2349 & $179.0(172.0 ; 184.0)$ & $170.0-185.0$ & 93 & $140.0(117.0 ; 190.0)$ & $117.0-194.0$ \\
\hline Jakarta+DIY +Bali & 315 & $258.0(232.0 ; 271.0)$ & $197.0-257.0$ & 833 & 212.0 (200.0: 224.0) & $172.0-215.0$ & 32 & $169.5(140.0 ; 246.0)$ & $97.0-202.0$ \\
\hline NTB-NTT & 347 & $168.0(155.0 ; 181.5)$ & $143.0-221.0$ & 591 & $137.0(129.0 ; 151.0)$ & $127.0-159.0$ & 28 & $122.0(94.5 ; 163.5)$ & $64.0-488.0$ \\
\hline Maluku+Papua & 206 & $209.0(203.8 ; 240.7)$ & $142.0-197.0$ & 386 & $180.0(165.0 ; 199.9)$ & $162.0-210.0$ & 19 & $131.0(101.0 ; 164.0)$ & $39.0-261.0$ \\
\hline \multicolumn{10}{|l|}{ Salt production } \\
\hline Salt producing provinces ${ }^{*}$ ) & 3442 & $221.0(215.0 ; 227.0)$ & $199.0-218.0$ & 7476 & $189.0(186.0 ; 193.0)$ & $185.0-198.0$ & 316 & $163.0(149.0 ; 187.0)$ & $158.0-212.0$ \\
\hline Non salt producing provinces & 2707 & $209.0(204.0 ; 215.5)$ & $178.0-198.0$ & 5742 & $188.0(184.0 ; 193.0)$ & $175.0-187.0$ & 262 & $174.5(161.0 ; 191.0)$ & $132.0-193.0$ \\
\hline
\end{tabular}


Table 2

Comparison of MUIC ( $\mu \mathrm{g} / \mathrm{L})$ among School Age Children, Women at Reproductive Age, and Pregnant Women by Household's lodized Salt Test, 2013

\begin{tabular}{|c|c|c|c|c|c|c|c|c|c|}
\hline \multirow{3}{*}{ Test for HH's lodized salt } & \multicolumn{9}{|c|}{ Urinary lodine Concentration $(\mu \mathrm{g} / \mathrm{L})$} \\
\hline & \multicolumn{3}{|c|}{ School Age Children } & \multicolumn{3}{|c|}{ Women at Reproductiive Age } & \multicolumn{3}{|c|}{ Pregnant Women } \\
\hline & $\mathrm{N}$ & Median (Low er; Upper) & Interquartile range & $\mathrm{N}$ & Median (Low er; Upper) & Interquartile range & $\mathrm{N}$ & Median (Low er; Upper) & Interquartile range \\
\hline \multicolumn{10}{|l|}{ Semi quantitative } \\
\hline lodized & 4667 & $227.0(221.0 ; 232.0)$ & $192.0-205.0$ & 10179 & $200.0(196.0 ; 202.0)$ & $186.0-196.0$ & 453 & $180.0(165.0 ; 193.0)$ & $151.0-200.0$ \\
\hline Non-lodized & 1449 & $183.0(173.0 ; 189.0)$ & $177.0-209.0$ & 2967 & $153.0(147.0 ; 157.5)$ & $150.0-163.0$ & 122 & $132.0(112.5 ; 154.0)$ & $116.0-212.0$ \\
\hline \multicolumn{10}{|l|}{ Titration } \\
\hline Non-lodized & 403 & $173.0(162.0 ; 187.0)$ & $139.0-190.0$ & 841 & $154.0(144.0 ; 164.0)$ & $143.0-172.0$ & 44 & $114.0(86.1 ; 139.5)$ & $69.0-182.0$ \\
\hline Inadequate lodized & 2321 & $202.0(195.0 ; 207.0)$ & $176.0-196.0$ & 5030 & $170.5(166.0 ; 175.0)$ & $163.0-177.0$ & 214 & $165.0(146.5 ; 184.0)$ & $137.0-199.0$ \\
\hline Adequate lodized & 2215 & $237.0(119.0 ; 245.0)$ & $195.0-217.0$ & 4830 & $211.0(206.0 ; 217.0)$ & $191.0-203.0$ & 208 & $189.0(163.5 ; 209.0)$ & $148.0-220.0$ \\
\hline Over-iodized & 203 & $281.0(256.0 ; 305.0)$ & $212.0-288.0$ & 463 & $222.0(206.0 ; 249.0)$ & $225.0-298.0$ & 18 & $237.5(112.5 ; 369.0)$ & $163.0-367.0$ \\
\hline
\end{tabular}


Table 3

Comparison of MUIC ( $\mu \mathrm{g} / \mathrm{L})$ among School Age Children, Women at Reproductive Age, and Pregnant Women by Household's lodized Salt using Titration and Socio-Economic Status, 2013

\begin{tabular}{|c|c|c|c|c|c|c|c|c|c|}
\hline \multirow{3}{*}{ Test for HH's lodized salt } & \multicolumn{9}{|c|}{ Urinary lodine Concentration $(\mu \mathrm{g} / \mathrm{L})$} \\
\hline & \multicolumn{3}{|c|}{ School Age Children } & \multicolumn{3}{|c|}{ Women at Reproductiive Age } & \multicolumn{3}{|c|}{ Pregnant Women } \\
\hline & $\mathrm{N}$ & Median (Low er; Upper) & Interquartile range & $\mathrm{N}$ & Median (Low er; Upper) & Interquartile range & $\mathrm{N}$ & Median (Low er; Upper) & Interquartile range \\
\hline Quintile 1 & 835 & & & 1572 & & & 60 & & \\
\hline Non-lodized & 91 & $147.0(120.0 ; 187.0)$ & $121.0-243.0$ & 167 & $124.0(102.0 ; 143.0)$ & $110.0-174.0$ & 9 & $94.0(33.0 ; 136.0)$ & $31.0-155.0$ \\
\hline Inadequate lodized & 413 & $149.0(139.0 ; 166.9)$ & $139.0-189.0$ & 796 & $132.0(124.0 ; 141.0)$ & $129.0-157.0$ & 29 & $125.0(85.0 ; 141.4)$ & $61.0-187.0$ \\
\hline Adequate lodized & 302 & $204.0(176.0 ; 229.5)$ & $168.0-220.0$ & 558 & $178.0(167.0 ; 193.9)$ & $191.0-203.0$ & 22 & $170.0(120.0 ; 209.0)$ & $72.0-239.0$ \\
\hline Over-iodized & 29 & $304.0(181.0 ; 416.0)$ & $263.0-496.0$ & 51 & $218.0(181.5 ; 261.0)$ & $131.0-320.0$ & 0 & & \\
\hline Quintile 2 & 996 & & & 2107 & & & 82 & & \\
\hline Non-lodized & 100 & $167.0(137.0 ; 191.5)$ & $110.0-196.0$ & 184 & $158.0(138.0 ; 183.0)$ & $134.0-227.0$ & 14 & $88.5(61.0 ; 219.0)$ & $39.0-385.0$ \\
\hline Inadequate lodized & 458 & $201.5(183.0 ; 216.0)$ & $154.0-198.0$ & 984 & $162.0(153.0 ; 173.0)$ & $163.0-177.0$ & 38 & $141.0(101.0 ; 180.9)$ & $77.0-202.0$ \\
\hline Adequate lodized & 398 & $227.5(212.0 ; 244.9)$ & $174.0-227.0$ & 850 & $204.0(191.0 ; 222.0)$ & $180.0-215.0$ & 29 & $181.0(123.0 ; 207.9)$ & $84.0-278.0$ \\
\hline Over-iodized & 40 & $243.0(197.0 ; 357.0)$ & $155.0-301.0$ & 89 & $208.0(161.0 ; 250.0)$ & $192.0-324.0$ & 1 & & \\
\hline Quintile 3 & 1133 & & & 2480 & & & 107 & & \\
\hline Non-lodized & 78 & $181.5(158.0 ; 203.0)$ & $81.0-219.0$ & 173 & $153.0(141.0 ; 174.0)$ & $138.0-194.0$ & 7 & $122.0(71.5 ; 363.0)$ & $33.0-305$ \\
\hline Inadequate lodized & 509 & $205.6(193.5 ; 216.0)$ & $164.0-209.0$ & 1105 & $180.0(168.0 ; 187.0)$ & $162.0-184.0$ & 43 & $167.0(140.0 ; 184.0)$ & $70.0-237.0$ \\
\hline Adequate lodized & 506 & $240.0(224.0 ; 255.9)$ & $166.0-219.0$ & 1098 & $213.0(203.0 ; 223.0)$ & $179.0-210.0$ & 49 & $199.0(158.0 ; 278.0)$ & $139.0-249.0$ \\
\hline Over-iodized & 40 & $262.0(220.0 ; 361.0)$ & $156.0-318.0$ & 104 & $259.5(200.5 ; 309.0)$ & $214.0-343.0$ & 8 & $236.5(131.0 ; 382.0)$ & $64.0-347.0$ \\
\hline Quintile 4 & 1217 & & & 2743 & & & 129 & & \\
\hline Non-lodized & 86 & $171.5(154.0 ; 218.0)$ & $119.0-217.0$ & 180 & $178.5(152.0 ; 196.0)$ & $125.0-187.0$ & 8 & $148.0(110.0 ; 165.0)$ & $18.0-239.0$ \\
\hline Inadequate lodized & 533 & $226.0(205.0 ; 243.0)$ & $180.0-218.0$ & 1194 & $198.0(181.0 ; 194.9)$ & $169.0-196.0$ & 61 & $212.0(152.6 ; 252.0)$ & $134.0-318.0$ \\
\hline Adequate lodized & 547 & $247.0(228.0 ; 261.0)$ & $203.0-246.0$ & 1257 & $220.0(209.0 ; 231.0)$ & $187.0-217.0$ & 56 & $223.0(181.0 ; 265.9)$ & $139.0-278.0$ \\
\hline Over-iodized & 51 & $297.0(264.0 ; 372.0)$ & $201.0-422.0$ & 112 & $223.0(201.0 ; 273.0)$ & $178.0-232.0$ & 4 & $235.0(42.0 ; 454.0)$ & $52.0-412.0$ \\
\hline Quintile 5 & 961 & & & 2262 & & & 106 & & \\
\hline Non-lodized & 48 & $228.0(169.0 ; 267.4)$ & $136.0-274.0$ & 137 & $158.0(141.0 ; 175.0)$ & $111.0-2017.0$ & 6 & $141.0(47.0 ; 192.0)$ & $31.0-179.0$ \\
\hline Inadequate lodized & 408 & $220.0(204.0 ; 234.0)$ & $172.0-213.0$ & 951 & $186.0(173.5 ; 195.0)$ & $153.0-186.0$ & 43 & $206.0(140.0 ; 232.0)$ & $113.0-266.0$ \\
\hline Adequate lodized & 462 & $252.0(236.0 ; 265.0)$ & $184.0-228.0$ & 1067 & $221.0(210.0 ; 231.9)$ & $176.0-202.0$ & 52 & $162.5(141.0 ; 234.0)$ & $111.0-311.0$ \\
\hline Over-iodized & 43 & $291.0(246.0 ; 339.0)$ & $132.0-341.0$ & 107 & $219.0(168.0 ; 285.0)$ & $217.0-342.0$ & 5 & $210.0(47.0 ; 529.0)$ & $82.0-492.0$ \\
\hline
\end{tabular}




\section{CONCLUSION AND RECOMMENDATION}

\section{Conclusion}

The detrimental effect of iodine deficiency on the mental and physical development of children as well as on the women of reproductive age has been recognized. Deficiency in pregnancy is particularly detrimental as it impact upon the unborn child. In Indonesia, the median urinary iodine concentration is in the normal range nationally, but some sub-populations in particular pregnant women remain deficient.

\section{Recommendation}

For the prevention of lodine disorders, it is recommended that coverage of adequateiodized salt need to be improved in order to ensure adequate iodine status for all sub-populations. It is also recommended to regularly monitor the iodine status of all three groups in order to ensure optimal iodine status including the avoidance of both iodine deficiency and excess.

It would be appropriate if Indonesia continues to tackle the large proportion of inadequately iodized salt as well as continues to identify the additional source of iodine intake that would contribute to the optimal iodine status.

\section{ACKNOWLEDGEMENT}

The Basic Health Research (RISKESDAS 2013) was funded and conducted by National Institute of Health Research and Development, Ministry of Health of the Republic of Indonesia; the analysis and reporting funded by Global Alliance for Improved Nutrition (GAIN).

\section{REFERENCES}

1. Zimmerman, MB, Jooste PI, Pandav CS. lodine-deficiency disorders. Lancet. 2008; 372: 1251-62.

2. WHO, UNICEF \& International Council for Control of lodine Deficiency Disorders (ICCIDD). Assessment of lodine Deficiency Disorders and Monitoring Their Elimination: A Guide for program managers. $3^{\text {rd }}$ ed. Geneva: WHO, UNICEF \& ICCIDD, 2007.

3. Brownstein D. lodine: Why you need it, why you can't live without it. Medical
Alternatives Press, West Bloomfield, Michigan, 2006.

4. Rohner F, Zimmerman MB, Jooste P, et al. Biomarkers of nutrition for development iodine review. J Nutr. 2014; 8: 1321S-42S

5. WHOrganization. Fortification of Food Grade Salt with lodine for Prevention and Control of lodine Deficiency Disorders. Guideline. Geneva: WHO, 2014.

6. Indonesia, Ministry of Health $(\mathrm{MOH})$. Laporan Riset Kesehatan Dasar (Riskesdas) 2007. Jakarta: Badan Litbangkes, 2008.

7. Indonesia, $\mathrm{MOH}$. Laporan Riset Kesehatan Dasar (Riskesdas) 2013. Jakarta: Badan Litbangkes, 2014.

8. Pusat Penelitian dan Pengembangan Gizi dan Makanan dan UNICEF. Survei Indikator Gangguan Akibat Kekurangan lodium: Riset Kesehatan Dasar (Riskesdas). Jakarta: Puslitbang Gizi dan Makanan dan UNICEF, 2008.

9. WHO. Assessment of iodine deficiency disorders and monitoring their elimination: a guide for programme managers. $3^{\text {rd }}$ edition. Geneva: WHO, 2007.

10. UNICEF. Program Brief: Updated guidance to support the monitoring and assessment of USI programs. 2016

11. Zimmermann MB, Boelaert K. Review: lodine deficiency and thyroid disorders. Lancet. 2015; 3(4): 286-95. http://dx.doi.org/10.1016/S22138587(14)70225-6.

12. Kapil U. Health Consequences of lodine Deficiency. Sultan Qaboos University Med J. 2007 Dec; 7(3): 267-272.

13. Leung AM, Braverman LE. Consequences of excess iodine. Nat Rev Endocrinol. 2013; 10(3): 136-42.

14. Piccone N. The Silent Epidemic of lodine Deficiency. Life Extension Magazine, 2006. http://www.lifeextension.com/magazine/201 1/10/the-silent-epidemic-of-iodinedeficiency/Page-01

15. Qian M, Wang D, Watkins WE, et al. The effects of iodine on intelligence in children: a meta-analysis of studies conducted in China. Asia Pac J Clin Nutr. 2005;14(1): 32-42.

16. Yaman AK, Demirel $F$, Ermiş $B$, Piş kin IE. Maternal and neonatal urinary iodine status and its effect on neonatal TSH levels 
in a mildly iodine-deficient area. $J$ Clin Res

Pediatr Endocrinol. 2013; 5(2): 90-4. 